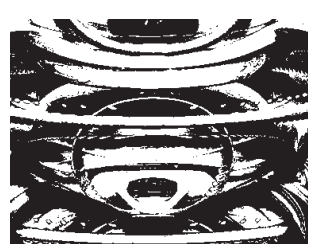

doi:10.5559/di.22.4.06

\title{
WORK STRESS AND MARITAL QUALITY IN DUAL EARNER COUPLES: A TEST OF THREE MEDIATION MODELS
}

\author{
Josip OBRADOVIĆ, Mira ČUDINA-OBRADOVIĆ \\ Zagreb \\ UDK: 316.36:331.44 \\ 316.36:159.944.4-057.16 \\ Izvorni znanstveni rad \\ Primljeno: 22. 8. 2011.
}

This research was conducted on 340 full-time employed marital couples representing a proportional quota sample of inhabitants that live in Zagreb and its metropolitan area. The aim was to test the effect of stress on marital quality when mediated by three variables. Three models were created using mediator variables: Perception of negative spillover from work in the first model, Marital strain in the second model and Depression in the third model. Structural equation modeling (SEM) ML Robust was used to test the effect of work stress. Results show that work stress decreases marital quality via mediator variables in both marital partners. Although all three models fit the data, the explanatory power of the models was different. The model in which Marital strain was the mediator variable turned out to be the best in terms of explanatory power, explaining $26 \%$ of wives' and $17 \%$ of husbands' variance of the variable Marital quality. The obtained results are discussed and suggestions for further research of the topic are suggested.

Keywords: work stress, negative spillover, marital stress, depression, marital quality

$\triangle$ Josip Obradović, Tuškanac 31, 10000 Zagreb, Croatia. E-mail: josip.obradovic@gmail.com

Contemporary life is full of stressors, which creates a lot of frustrations, stress and unpleasant life experience. There is no doubt that work and family are two of the most important areas for everyone's life (Baloban \& Črpić, 2000), so stress in one or even both of these areas can make one's life difficult 
and miserable and even jeopardize his/her physical and mental health. In this paper we shall limit our interest to its impact on the family, more precisely, on some of the important marital processes, such as marital quality.

\section{CONCEPTUALIZATION OF WORK STRESS}

Since stress has become a popular study concept, many conceptualizations have been proposed: Kahn \& Byosiere, 1992; Selye, 1950 and many others. Selye (1950) defined stress in the physiological sense as a nonspecific arousal reaction in response to situations that require mobilization of energy. Subsequent definitions of stress improved Selye's definition (1950) making formulations more precise. Hence we know nowdays what is meant by work stress, how it is manifested and how it can be operationalized as well measured. Here we shall use a popular definition offered by Dipboye, Smith, and Howell (1994, p. 290), according to which "work stress is any circumstance that places special physical and/or psychological demands on a person that an unusual or out-of-the-ordinary response occurs".

Work stress is manifested by physiological and psychological symptoms while, according to many studies, the occurrence and intensity of the symptoms depend on numerous moderators (Rook, Dooley, \& Catalano, 1991). Some theoretical models of work stress were proposed with the aim to explain work stress itself and variables or stressors which determine its intensity (Elliot \& Eisdorfer, 1982; French, Caplan, \& Harrison, 1982). Interest in work stress and its impact was mostly focused on the work performance or generally, on work behavior for a long time. Later, it was broadened to encompass outcomes such as employees' health and life satisfaction. Subsequently, it was understood that work stress can influence out-of-work behavior and spill over into other-than-work domains. Many hypothetical opinions appeared concerning the relationship between work stress and out-of-work life, and soon the research results pointed to the reality of spillover from the work to non-work domain, particularly to employees' health, leisure and family life (Bolger, DeLongis, Kessler, \& Wethington, 1989; Lewin-Epstein, 1989).

\section{WORK STRESS SPILLOVER}

Indeed, many studies conducted on different samples have clearly demonstrated that negative work experiences and work stress in particular are not forgotten and left behind in the work place. Instead, employees bring them home at the expense of their family life and relations (Schneewind \& Kupsch, 2007; Steenbergen, Kluwer, \& Karney, 2011). For example, feelings 
DRUŠ. ISTRAŽ. ZAGREB GOD. 22 (2013), BR. 4 STR. $673-691$

OBRADOVIĆ, J., ČUDINA-OBRADOVIĆ, M.: WORK STRESS... of being stressed at work have been related to self-reports of distress (Lavee \& Ben-Ari, 2007) and poor marital relationships (MacEwen, Barling, \& Kelloway, 1992; Sears \& Galambos, 1992). Similar results were obtained in studies in which a daily diary method, or observations of actual interactions between marital partners were carried out (Crouter \& Helms-Erikson, 1997). All these studies have shown that the short-term consequences of spillover can vary from the intensification of anger and conflict to withdrawal from interactions (Story \& Repetti, 2006). Long-term consequences were also noted and identified as depression, anxiety or general mental health deterioration (Jacobs, Tytherleigh, Webb, \& Cooper, 2007).

It seems that these problems are especially pronounced in dual-earner families. Employees who experience work overload and who also have responsibilities at home, those who have difficulties combining work and marriage / family roles represent the most vulnerable group (Paden \& Buehler, 1995). Even sheer physical exhaustion could be a very important work stressor creating feelings of distress and inadequate behavior in the family (Roberts \& Levenson, 2001). However, not all individuals react to the work stress identically. Some studies revealed that work stress spillover is more pronounced for husbands in poor quality marriages than for those satisfied in their marriage (Roberts \& Levenson, 2001). Education turned out to be an important buffer of work stress as better educated marital partners cope with it more successfully (Jacobs et al., 2007). Generally, it is safe to conclude that although marital partners can and do experience work stress spillover, its intensity varies depending on a host of moderators including gender, education, partner's support and marital quality (Conger, Rueter, \& Elder; 1999; Perry-Jenkins, Repetti, \& Crouter, 2000).

\section{WORK STRESS CROSSOVER}

The husband's/wife's negative work experience does not only affect his/her own subjective states, but also his/her partner's and even children's behavior (Jones, Burke, Ronald, \& Westman, 2006; Goodman, Crouter, Lanza, Cox, \& Vernon-Feagans, 2011; Westman, 2001; Westman, Vinokur, Hamilton, \& Roziner, 2004). The various effects of work stress on a partner's feelings and reactions can be noted. For example, the wife can react aggressively, or be emotionally indifferent or withdrawn from the situation, being unable or refusing to understand her husband's problems (Rook et al., 1991). On the other hand, wives who do identify with their husbands show signs of anxiety, depression, or general distress (Rook et al., 1991). Hence, the intensity of the crossover effect varies and depends on numerous moderators, most often on marital quality and the exi- 
DRUŠ. ISTRAŽ. ZAGREB GOD. 22 (2013), BR. 4, STR. 673-691

OBRADOVIĆ, J., ČUDINA-OBRADOVIĆ, M. WORK STRESS... stence of the partner's emotional support (Ford, Heinen, \& Longkamer, 2007; Repetti \& Saxbe, 2009). Marital quality and emotional support are two closely connected variables. Partners in poor quality marriages who do not offer or receive any support should experience no crossover and more pronounced spillover effect, while both crossover and spillover effects might be present among partners in good quality marriages, the second being less pronounced because of the partner's support.

However, when discussing research results of work stress impact on marital partners' behavior, one must take some important limitations into consideration. Firstly, most or almost all of the results come from the USA - a highly developed society in economic terms with a pronounced individualistic values orientation. It is therefore debatable whether these results and conclusions are also valid for less developed societies, especially those with a less pronounced individualistic orientation, where solidarity and support among family members is of utmost importance. To the best of our knowledge, this question is still without an appropriate answer. Secondly, most of the presented research is characterized by a complete disregard for the marital context comprising marital interactions. Concretely, in most studies on work stress spillover and crossover on marital partners' behavior, the independent effect of work stress is assumed automatically, disregarding that the marital dyad behavior of one marital partner depends on the behavior of the other partner, or that there is some interdependence of marital partners' behavior. Due to this disregard of social context and interdependence of marital partners' behavior, we believe that proper insight into the impact of work stress on marital processes, particularly marital quality, has not been explored in a satisfactory way.

\section{PRESENT STUDY}

The aim of the study is to test the effect of work stress as experienced by each marital partner on their marital quality. In contrast to previously cited studies, we included both marital partners because we assume interdependence between marital partners' behavior in this study. For this purpose we used the Actor-Partner Interdependence Model (APIM), designed to assess causal associations between personal variables at the level of dyad members. "The fundamental assumption of the APIM is that $X$ causes $Y$. We could treat the APIM as a prediction model (i.e. $X$ is used to predict $Y$ ), but, typically, the assumption is that $X$ causes $Y$. Thus, if there were actor and partner effects, a change in $X$ would lead to change in both $Y_{1}$ and Y2" (Kenny, Kashy, \& Cook, 2006, p. 181). In other words, 
DRUŠ. ISTRAŽ. ZAGREB GOD. 22 (2013), BR. 4 STR. $673-691$

OBRADOVIĆ, J., ČUDINA-OBRADOVIĆ, M.: WORK STRESS... the APIM is a model of dyadic relationships that control for artificial increases in Type I and Type II errors by accounting for non-independence of dyadic data. This model estimates two types of effects: 1 . Actor effects describe the association between a person's score on an independent variable and their own score on an outcome variable, and, 2. Partner effects describe the association between a person's score on a predictor variable and his or her partner's score on an outcome variable (Ledermann \& Macho, 2009). In our study we used the extended APIM called APIeM (Ledermann, Macho, \& Kenny, 2011). In such a model there are three sets of variables: exogenous, mediating and outcome variables. The mediation or intervening variables play an important role because in many cases exogenous variables do not directly, but via mediation variables affect outcome variables. In the APIeM model, an exogenous variable $(\mathrm{X})$ affects mediator variable (M) designated as a, a mediation variable (M) affects an outcome variable designated as $b$, and an exogenous variable $(X)$ affects an outcome variable $(\mathrm{Y})$ designated as c; mediating or indirect effect IE of $\mathrm{X}$ on $\mathrm{Y}$ equals $\mathrm{ab}$ and the total effect equals $a b+c^{\prime}$ (Ledermann, Macho \& Kenny, 2011). In our study, such an approach allows verification of work stress spillover, crossover and effect between marital partners' behavior, giving better insight into the effects of work stress on marital quality than studies disregarding the interdependence of marital partners' behavior (Kenny, 1996; Kenny et al., 2006). In our study we included three mediators: Perception of negative spillover from work, Marital strain and Depression. In many studies these variables proved to be important mediators between work stress and marital processes (Repetti \& Saxbe, 2009), but so far their mediation power has not been tested in the same study. Mediation power is the proportion of the variance of the outcome variable explained by the mediator variable. The inclusion of mediator variables was indispensable because we assume that work stress affects marital processes indirectly, being increased or decreased by mediator variables. The baseline theoretical model is presented in Figure 1. We assume 6 actors effects indexed as A and 6 partners effects indexed as P.

As presented in Figure 1 we assumed a positive relationship between wives' and husbands' work stress. We also assumed that work stress affects mediator variables, which then affect the dependent variable Marital quality. Since there are three mediators and because we assumed different work stress effects on different mediators, there are three models or groups of hypotheses about the relationship between the exogenous variable Work stress, mediator variables and dependent variable Marital quality. 


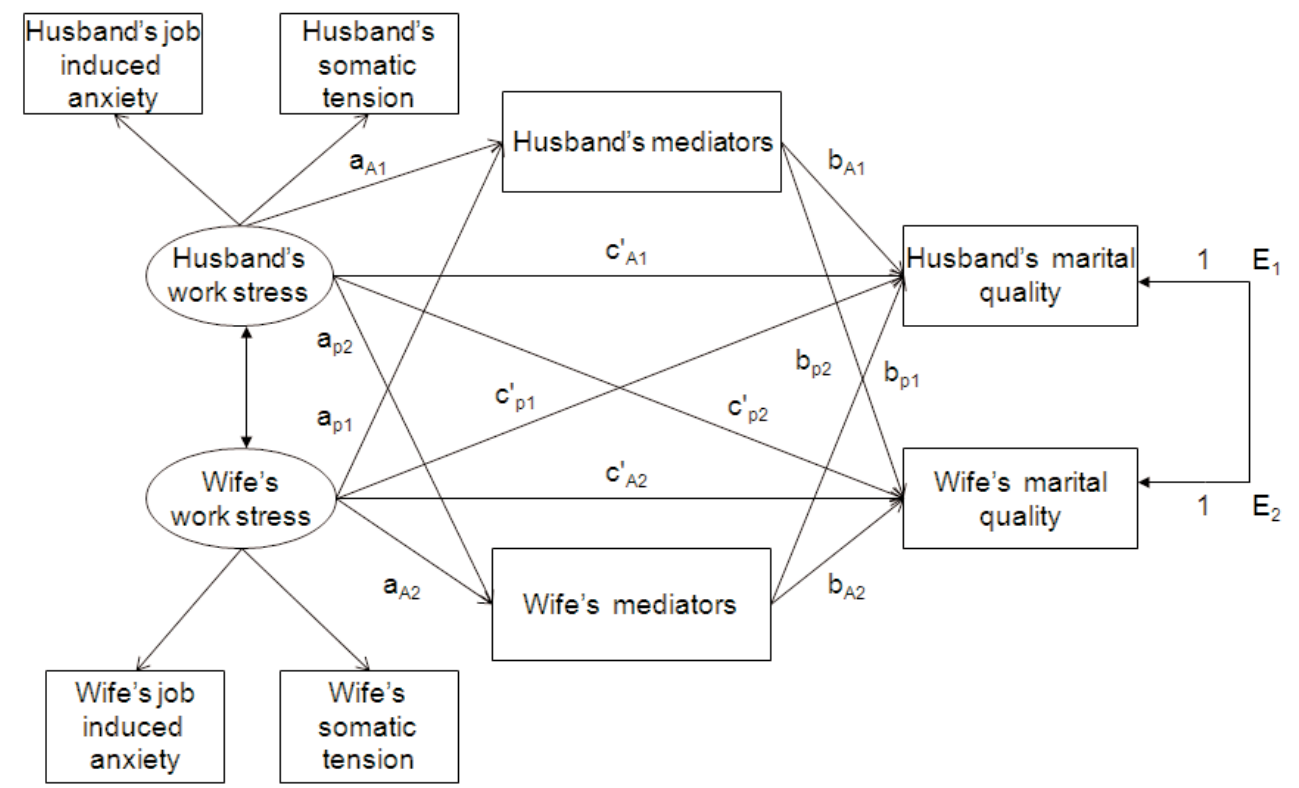

i FIGURE 1

General theoretical model of the relationship between work stress and marital quality (latent constructs are shown in ellipses and observed variables in rectangles)

\section{METHOD}

\section{Participants}

Model 1 takes the variable Perception of negative spillover from work as a mediator. Our assumption is that the work stress of both marital partners will increase their perception of negative spillover from work (Aa1 and $\mathrm{Ap}_{\mathrm{p}}$ ) and (Aa2 and $A_{p 2}$ ), actor and partner effect as well as mediation variables will in turn decrease marital quality in the dyad indexed as $\mathrm{Ba} 1$ and $\mathrm{Ba} 2$ (Actors effect) and mediating variables indexed as $\mathrm{B}$ p1 and $\mathrm{B}$ 22 (Partners effect). Eventually, we assumed the actor effects of both marital partners' exogenous variable (work stress) on the dependent variable marital quality indexed as $\mathrm{C}^{\prime} \mathrm{a} 1$ and $\mathrm{C}^{\prime} \mathrm{a} 2$ and partner effects indexed as $\mathrm{C}_{\mathrm{p} 1}^{\prime}$ and $\mathrm{C}_{\mathrm{p} 2 \text {. Similar }}$ relationships were assumed among the exogenous, mediating and outcome variables in the other two models.

Model 2 takes the variable Marital strain as a mediator variable and Model 3 takes the variable Depression as a mediator variable. Our assumption is that both, husbands' and wives' work stress affects or increases marital strain and depression as experienced by both marital partners, and consequently that both partners' variables then decrease marital quality in the dyad.

The participants in our study included 340 dual-earner couples representing a proportional quota sample of employed individuals that live in the city of Zagreb, the capital of Croatia, and the metropolitan area of Zagreb on the variable hus- 
DRUŠ. ISTRAŽ. ZAGREB GOD. 22 (2013), BR. 4 STR. $673-691$

OBRADOVIĆ, J., ČUDINA-OBRADOVIĆ, $M$ : WORK STRESS... band's education. Both marital partners were employed full-time. The mean age of the wife was $\mathrm{M}=35.00(\mathrm{SD}=8.16)$ years and the mean age of the husband was $\mathrm{M}=38.28$ ( $\mathrm{SD}=7.82$ ). Out of the total number of wives, $17.64 \%$ had elementary school education (8 years of schooling), $47.62 \%$ had a high school education (twelve years of schooling) and $34.70 \%$ were college or university graduates (sixteen years of schooling). Out of the total number of husbands, $27.64 \%$ had elementary school education, $42.05 \%$ had a high school education and $30.31 \%$ were college or university graduates. Out of the total number of wives, $63.82 \%$ never work overtime, $24.12 \%$ work several times a month and $10.88 \%$ work overtime several times a week. Husbands work overtime more frequently: $35.59 \%$ never work overtime, $40.88 \%$ several times per month and $23.53 \%$ work overtime several times a week. The majority of wives work in one shift only: $67.65 \%$ only in the morning, $27.65 \%$ in the morning and afternoon and $4.7 \%$ in the morning, afternoon and night shift. On the other hand, $65.59 \%$ of husbands work only in the morning, $19.20 \%$ in the morning and afternoon and $15.29 \%$ work in all three shifts. The mean marriage length in the sample was $\mathrm{M}=12.31$ years: $(\mathrm{SD}=$ 7.68).

\section{Variables and measures}

\section{Exogenous variable}

The variable Work stress represents a latent structure derived from two indicator variables or subscales that are a part of the Anxiety-Stress Questionnaire (House \& Rizzo, 1972). Originally, the Anxiety-Stress Questionnaire consists of three subscales: Job induced anxiety, Somatic tension and General fatigue and uneasiness. In our study, we used the first two subscales because of their satisfactory reliability and also because after factor analysis they proved to have measured one factor.

Job induced anxiety. This variable is a continuous scale consisting of 7 items with $1=$ Yes and $0=$ No format. The sum of all Yes answers represents the intensity of anxiety induced by work. A sample of items includes: "I feel fidgety or nervous because of my job", or "Problems associated with work kept me awake at night". The obtained internal consistency Cronbach $\alpha$ was 0.88 , for both wives and husbands.

Somatic tension. This variable was measured by a subscale consisting of 5 items with $1=$ Yes and $2=$ No format. A sample of items includes: "I have trouble with my digestion", or "I am often bothered by acid indigestion or heartburn". The obtained internal consistency Cronbach $\alpha$ for both marital partners was $\alpha=0.82$. Both variables were satisfactorily loaded on the latent structure variable Work stress $(>0.50)$. 
DRUŠ. ISTRAŽ. ZAGREB GOD. 22 (2013), BR. 4, STR. $673-69$

OBRADOVIĆ, J., ČUDINA-OBRADOVIĆ, M. WORK STRESS...

\section{Mediation variables}

1. The variable Negative spillover from work represents a latent structure derived from two indicator variables or subscales: Negative spillover on the marriage and Negative spillover on the household (Small \& Riley, 1990).

Negative spillover on the marriage is a continuous scale consisting of five items each with five-point interval format from $1=$ absolutely disagree to $5=$ absolutely agree. A sample of items includes: "My job keeps me from spending time with my spouse" or "My marriage suffers because of my work". A higher score indicates more intensive negative spillover. The obtained internal consistency Cronbach $\alpha$ for wives was 0.85 and 0.82 for husbands.

Negative spillover on the household is also a continuous scale consisting of five items each with five point interval format from $1=$ absolutely disagree to $5=$ absolutely agree. A sample of items includes: "I spend so much time working that I am unable to get much done at home" or "When I get home from my job, I do not have the energy to get work done". A higher score indicates more intense negative spillover. The obtained internal consistency Cronbach $\alpha$ for wives was 0.87 and 0.81 for husbands. Both variables were satisfactorily loaded on the variable Negative spillover from work $(>0.50)$.

2. The variable Marital strain is measured by the McCubbin, Thompson, and McCubbin scale (1996) consisting of four items each with two point format: $1=$ Yes and $0=$ No. If a particular stressor was present in the marriage, the partners were asked to check in what degree it was stressful for him/her on the five point scale from $1=\mathrm{I}$ was not stressed at all to $5=\mathrm{I}$ was stressed very much. A sample of items includes: "I had an increase in sexual difficulties in the relationship with my partner" or "My partner had a love affair". A higher score indicates higher marital strain. The obtained internal consistency Cronbach $\alpha$ for wives was 0.97 and 0.95 for husbands.

3. The variable Depression was measured by the CES-D Inventory (Center for Epidemiological Studies Depression Inventory (Radloff, 1977). It is a frequently used self-report scale that assesses the current level of depressive symptoms, with emphasis on the affective component, depressed mood. The scale consists of twenty items each with a four point interval format: $1=$ rarely or none of the time (less than 1 day), $2=$ some or a little of the time (1-2 days), $3=$ occasionally or a moderate amount of time (3-4 days) and $4=$ most or all of the time (5-7 days). A sample of items includes: "I was bothered by the things that usually don't bother me" or "I had trouble keeping my mind on what I was doing". The scale measures four factors: 1. Depressed affect (blues, depressed, lonely), 2. Positive 
DRUŠ. ISTRAŽ. ZAGREB GOD. 22 (2013), BR. 4 STR. 673-691

OBRADOVIĆ, J. ČUDINA-OBRADOVIĆ, M. WORK STRESS... affect (good, hopeful, happy, enjoyed life), 3. Somatic retarded activity (bothered, poor appetite, everything was effort, restless sleep, couldn't get going), 4. Interpersonal (unfriendly, disliked). Items measuring factor 2 (Positive affect) were reverse coded and after that, answers on all items were summed up. A higher score indicates more intensive depression. The obtained internal consistency Cronbach $\alpha$ for wives was 0.95 and 0.97 for husbands.

\section{Dependent variable}

The variable Marital quality was measured by the MQI (Marital Quality Index) developed by Norton (1983). The scale has been used and validated in many studies (Funk \& Rogge, 2007; Heyman, Sayers, \& Bellack, 1994; Ledermann \& Macho, 2009). The original version of the scale consists of five items with seven-point interval format and one item with ten-point interval format. In this study, the scale was slightly revised and consists of six items of five point format ranging from $1=$ (strongly disagree) to $5=$ (strongly agree). A sample of items: "We have a good marriage" or: "My relationship with my partner makes me happy". A higher score indicates higher marital quality. The obtained internal consistency Cronbach $\alpha$ for both marital partners was 0.96 .

\section{RESULTS}

\section{Descriptive statistics}

(1) TABLE 1

Differences between wives and their husbands on measures included in the model
Before we evaluate the models, we shall present descriptive statistics showing similarities or differences and interdependencies between husbands and wives on the variables included in this study. These results are presented in Tables 1 and 2.

\begin{tabular}{|c|c|c|c|c|c|c|c|c|}
\hline \multirow[b]{2}{*}{ Measures } & \multicolumn{2}{|c|}{ Wives } & \multicolumn{2}{|c|}{ Husbands } & \multirow[b]{2}{*}{$\mathrm{df}$} & \multirow[b]{2}{*}{$\mathrm{t}$} & \multicolumn{2}{|c|}{ Cohen's } \\
\hline & $\mathrm{M}$ & $\mathrm{SD}$ & $\mathrm{M}$ & $\mathrm{SD}$ & & & $\mathrm{p}$ & d \\
\hline Job induced anxiety & 2.16 & 1.93 & 2.74 & 2.35 & 339 & 0.88 & 0.432 & 0.04 \\
\hline Somatic tension & 1.95 & 1.34 & 2.00 & 1.57 & 339 & 0.77 & 0.441 & -0.01 \\
\hline Negative spillover on the marriage & 10.45 & 2.85 & 9.91 & 3.02 & 339 & 2.77 & 0.006 & 0.21 \\
\hline Negative spillover on the household & 10.04 & 4.83 & 8.48 & 2.66 & 339 & 5.90 & 0.000 & 0.28 \\
\hline Marital strain & 1.78 & 3.37 & 1.18 & 2.30 & 339 & 3.51 & 0.001 & 0.12 \\
\hline Depression & 39.77 & 10.10 & 37.34 & 9.28 & 339 & 4.10 & 0.000 & 0.24 \\
\hline Marital quality & 23.08 & 5.81 & 23.51 & 5.47 & 339 & 1.31 & 0.191 & -0.09 \\
\hline
\end{tabular}

Note: $\mathrm{N}=340$ couples, paired-sample t test.

Table 1 presents the means, standard deviations, skewness, $\mathrm{t}$ tests and Cohen's d checking for the differences between husbands and wives on the variables included in this study. It is 
(1) TABLE 2

Intercorrelations for scores on measures included in the study worth noting that there is a significant difference between marital partners on the Negative spillover from work on the marriage, the Negative work spillover on the household, Marital strain, and Depression as mediation variables. According to the results, wives experience negative spillover more intensively, as well as marital strain and depression.

Table 2 presents intercorrelations between results on the exogenous, mediating and the dependent variable marital quality.

\begin{tabular}{|c|c|c|c|c|c|c|c|}
\hline Measures & 1 & 2 & 3 & 4 & 5 & 6 & 7 \\
\hline 1 Job induced anxiety & $0.13^{*}$ & $0.53^{* *}$ & $0.16^{*}$ & $0.14^{*}$ & 0.07 & $0.24^{*}$ & -0.06 \\
\hline 2 Somatic tension & $0.57^{* *}$ & $0.15^{* *}$ & $-0.18^{*}$ & $-0.17^{*}$ & $0.13^{*}$ & $0.34^{* *}$ & $-0.12^{*}$ \\
\hline 3 Negative spillover on the marriage & 0.06 & $0.14^{*}$ & $0.21^{* *}$ & $0.37^{* *}$ & 0.05 & -0.09 & -0.05 \\
\hline 4 Negative spillover on the household & 0.06 & 0.10 & $0.59 * *$ & $0.13^{*}$ & $0.19^{*}$ & $0.19^{*}$ & -0.18 \\
\hline 5 Marital strain & $0.33^{* *}$ & $0.34^{* *}$ & 0.02 & $0.17^{*}$ & $0.36^{* *}$ & $0.32^{* *}$ & $-0.52^{* *}$ \\
\hline 6 Depression & $0.31^{* *}$ & $0.38^{* *}$ & $0.20^{*}$ & $0.20^{*}$ & $0.31^{* *}$ & $0.37^{* *}$ & $-0.33^{* *}$ \\
\hline 7 Marital quality & -0.08 & $-0.18^{*}$ & -0.07 & -0.09 & $-0.35^{* *}$ & $-0.18^{*}$ & $0.45^{* *}$ \\
\hline
\end{tabular}

Note: Intercorrelations for wives $(\mathrm{N}=340)$ appear above the diagonal, and Intercorrelations for husbands $(\mathrm{N}=340)$ below the diagonal; correlations between wives and husbands appear in bold on the diagonal.

${ }^{*} \mathrm{p}<0.05,{ }^{* *} \mathrm{p}<0.01$

There is a high and positive correlation between the observed indicator variables of husbands' and wives' work stress - job induced anxiety and somatic tension (Table 2, diagonal cells). For both marital partners the correlations between Marital strain, and Marital quality are higher than correlations between Negative spillover from work on the marriage, Negative spillover of work on the household, Marital strain and Depression as mediating variables. The same correlations are also higher than those between job induced anxiety and somatic tension as indicator variables, Negative spillover on the marriage and the household, Marital strain and Depression as mediating, and Marital quality as dependent variable. It is important to emphasize that by this our assumption of the interdependence between marital partners' behavior is justified, as the correlations between variables of marital processes in the diagonal are positive and moderately high.

By using a preliminary ANOVA (Gender $2 \times 5$ levels of work stress) design, significant differences were obtained: $\mathrm{F}=2.41$, $p<0.05$, showing that both wives and husbands who experience higher work stress perceive lower level of marital quality. However, neither the difference between husbands and wives: $(F=0.834, p>0.05$,$) nor the interaction effect (F=0.089, p>0.05$. $)$ were significant, showing that work stress affects marital quality irrespectively of the partner's gender. 


\section{Evaluation of the models}

According to the general theoretical model, three mediator variables are defined (Negative spillover from work to marriage, Marital strain and Depression), yielding three models comprising three different set of hypotheses. First we shall present the obtained results for each model separately. Afterwards, we shall compare models pinpointing the direct, indirect and total effects and which model has the highest explanatory power. For models evaluation we used structural equation modeling (SEM), EQS program version 6.1, ML ROBUST method, for non normal data (Bentler \& Wu, 2006). The final structural models were fitted by adding standardized paths. The covariance matrix was used as an input and missing data were substituted by mean values of the corresponding variable (less than $2 \%$ of the data were missing.) Overall goodness of fit for each model was assessed by the $\chi^{2}$ statistics, Bentler's Comparative fit index CFI (Bollen \& Long, 1993), and Rootmean square error of approximation (RMSEA) in accordance with the guidelines suggested by Browne and Cudeck (1993) as well $\mathrm{Hu}$ and Bentler (1998), and MacCallum, Browne, and Sugawara (1996).

\section{Model 1}

As stated at the beginning, Model 1 presents Perception of negative spillover from work as a mediator variable. All the results of testing Model 1 are presented in Figure 2.

As an estimate of kurtosis we used the Mardia-based Kappa $=0.27$ that was completely satisfactory (Bentler, 2006). According to the obtained results (Figure 3), the variable Negative spillover turns out to be the mediator between Work stress and Marital quality. The parameter estimates show that the model fitted the data very well. ML ROBUST was $\chi^{2}=22.18$ with $\mathrm{df}=19$ and $\mathrm{p}>0.05, \mathrm{CFI}=0.994$ and RMSEA $=0.03$ with a Confidence interval CI (0.00-0.05). The latent structure variable Work stress is loaded satisfactorily (higher than 0.50 ) with the indicator variables for both marital partners. Work stress as an exogenous variable affects wives' and husbands' perception of Negative spillover from work; wives' $(\beta=0.27$, $p<0.05)$ and husbands' perception $(\beta=0.12, p<0.05)$. The mediator variable negative spillover from work affects husbands' $(\beta=-0.04, \mathrm{p}<0.05)$ and wives' $(\beta=-0.19, \mathrm{p}<0.05)$ marital quality. The more intensively marital partners perceive negative spillover, the less positively they perceive their marital quality. However, in interpreting statistically significant effects smaller than 0.10 , we should be careful, because some authors suggest that they should be ignored (Cohen, 1988). Out of 6 actor effects the highest is wife's work stress on wife's 
(1) FIGURE 2

Standardized coefficients for Model 1 (latent constructs shown in ellipses and observed variables in rectangles) negative spillover $\beta=0.27, \mathrm{p}<0.05$ and the highest partner effect is husband's work stress on the wife's negative spillover $\beta=0.24, p<0.05$, but the proportion of explained variance of the dependent variable Marital quality for both marital partners is very small. For wives it was $\mathrm{R}^{2}=0.05, \mathrm{p}<0.05$ and for husbands $\mathrm{R}^{2}=0.07, \mathrm{p}<0.05$.

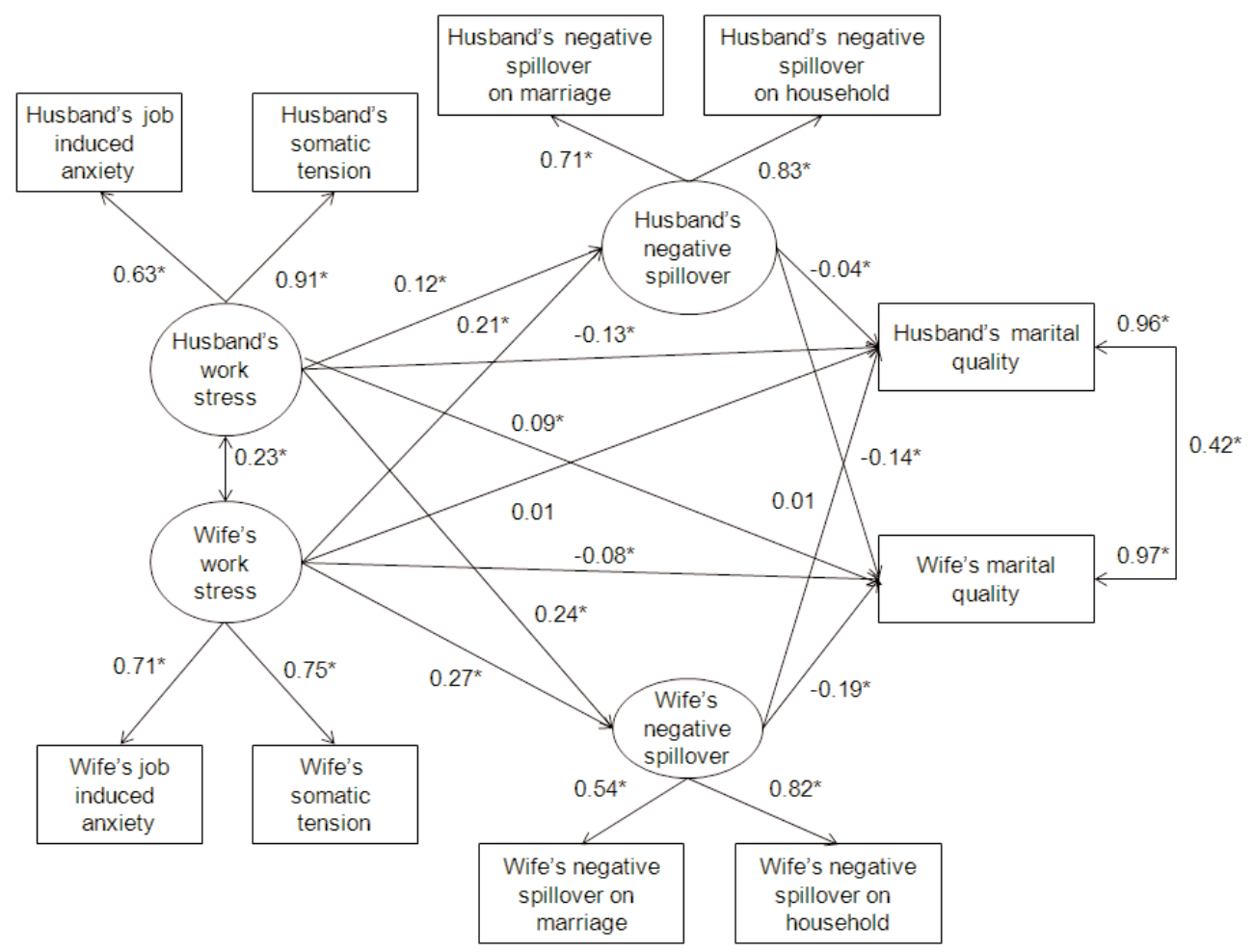

Model 2

In Model 2 Marital strain was posited as a mediator variable. As indicator of kurtosis we used Mardia-based Kappa 0.54 that was acceptable as in the previous model. According to the results, Model 2 fitted the data. ML ROBUST was $\chi^{2}=23.06$, $\mathrm{df}=8, \mathrm{x} 2 / \mathrm{df}=2.88, \mathrm{p}>0.05, \mathrm{CFI}$ is 0.94 and RMSEA $=0.08$ with a Confidence interval CI (0.06-0.12) that is acceptable (Bollen \& Long, 1993), and variable latent structure Work stress was satisfactorily loaded on indicator variables for both marital partners. According to the results, work stress affects husbands' and wives' marital quality. Standardized coefficients for Model 2 are presented in Figure 3.

The exogenous variable affects the mediator variable Marital strain for wives $(\beta=0.15, p<0.05)$ and husbands $(\beta=0.19$, $p<0.05)$. In other words, work stress increases marital strain for both marital partners, which then negatively affects both 
(1) FIGURE 3

Standardized

coefficients for Model

2 (latent constructs

shown in ellipses and observed variables in rectangles) partners' marital quality. It affects wives' marital quality more negatively $(\beta=-0.48, \mathrm{p}<0.05)$, than it does the marital quality of their husbands $(\beta=0.19, \mathrm{p}<0.05)$. Out of 6 actor effects the highest is wife's marital strain $(\beta=-0.48, p<0.05)$ and out of 6 partner effects the highest is wife's marital strain on husband's marital quality $(\beta=-0.25, \mathrm{p}<0.05)$. By this model more variance of marital quality was explained than with the previous one. For the wives, the obtained $\mathrm{R}^{2}$ is 0.26 and for the husbands, $\mathrm{R}^{2}=0.17$. In terms of the explained variance of the variable Marital quality, Model 2 is superior to Model 1.

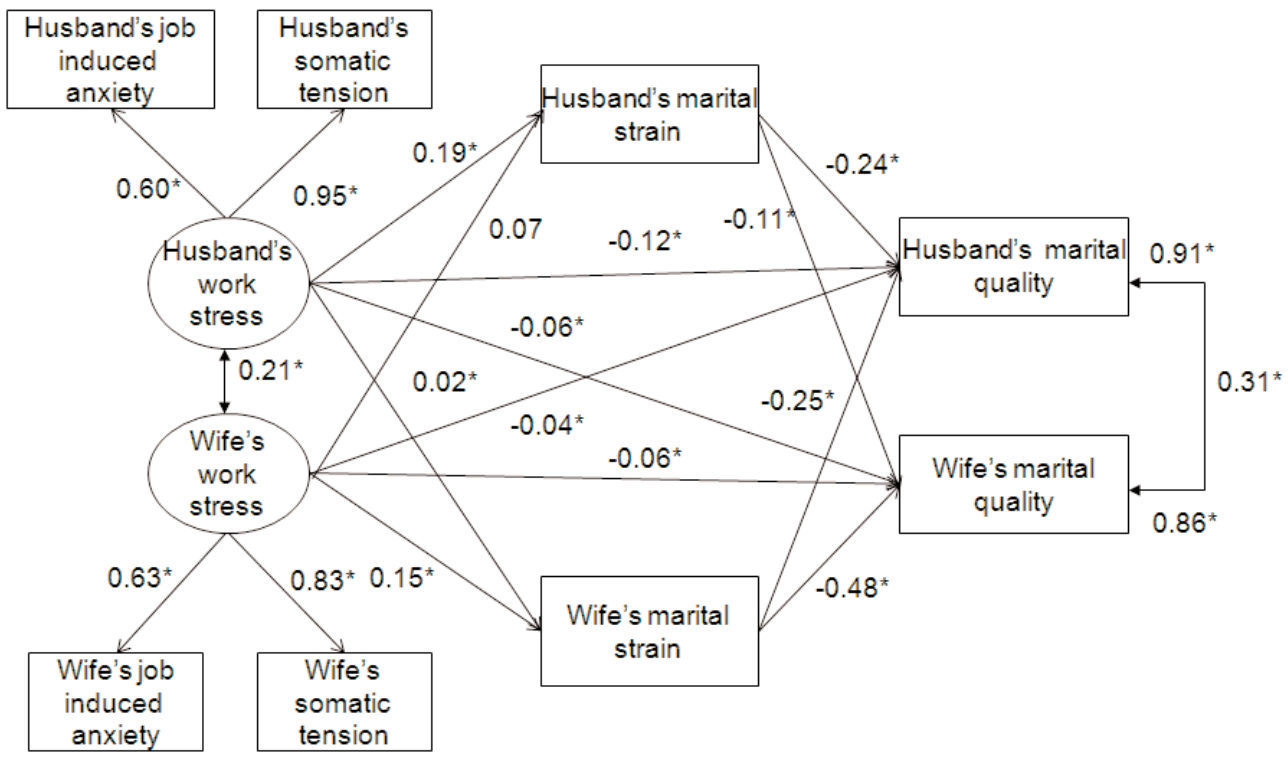

Model 3

In Model 3, like in the previous two models, Mardia-based Kappa as a measure of kurtosis is 0.23 or lower than in the first two models and completely acceptable. ML ROBUST $\chi^{2}=30.35$ with $\mathrm{df}=8, \mathrm{p}<0.01$, but CFI is 0.95 and RMSEA $=0.08$ with CI (0.05-0.12). Although $\chi^{2}$ is significant, other measures indicate a fit between the model and the data. Standardized coefficients showing actor and partner effects are presented in Figure 4 .

Actor effects show that husband's and wife's work stress affects or increases depression. For wives, $\beta=0.41$, $p<0.05$ and for husbands, $\beta=0.42, \mathrm{p}<0.05$. Actor effects also show that depression decreases a wife's, $\beta=-0.30$, $p<0.05$, and husband's, $\beta=-0.17, \mathrm{p}<0.05$, marital quality. The husband's work stress as an actor effect decreases the husband's marital quality, also $\beta=-0.10, \mathrm{p}<0.05$. Partner effects are lower. According to the results, the wife's work stress affects the hus- 
(1) FIGURE 4

Standardized coefficients for Model 3 (latent constructs shown in ellipses and observed variables in rectangles) band's depression $\beta=0.14, \mathrm{p}<0.05$ and depression affects the husband's marital quality $\beta=-0.09, \mathrm{p}<0.05$. Out of six actor effects, the highest is the husband's work stress on the husband's depression $\beta=0.42, \mathrm{p}<0.05$, and out of six partner effects, it is the wife's work stress on the husband's depression $\beta=0.14, \mathrm{p}<0.05$. With Model 3, a relatively low percentage of variance of the variable marital quality was explained. This was for wives $\mathrm{R}^{2}=0.11$, and for husbands $\mathrm{R}^{2}=0.08$.

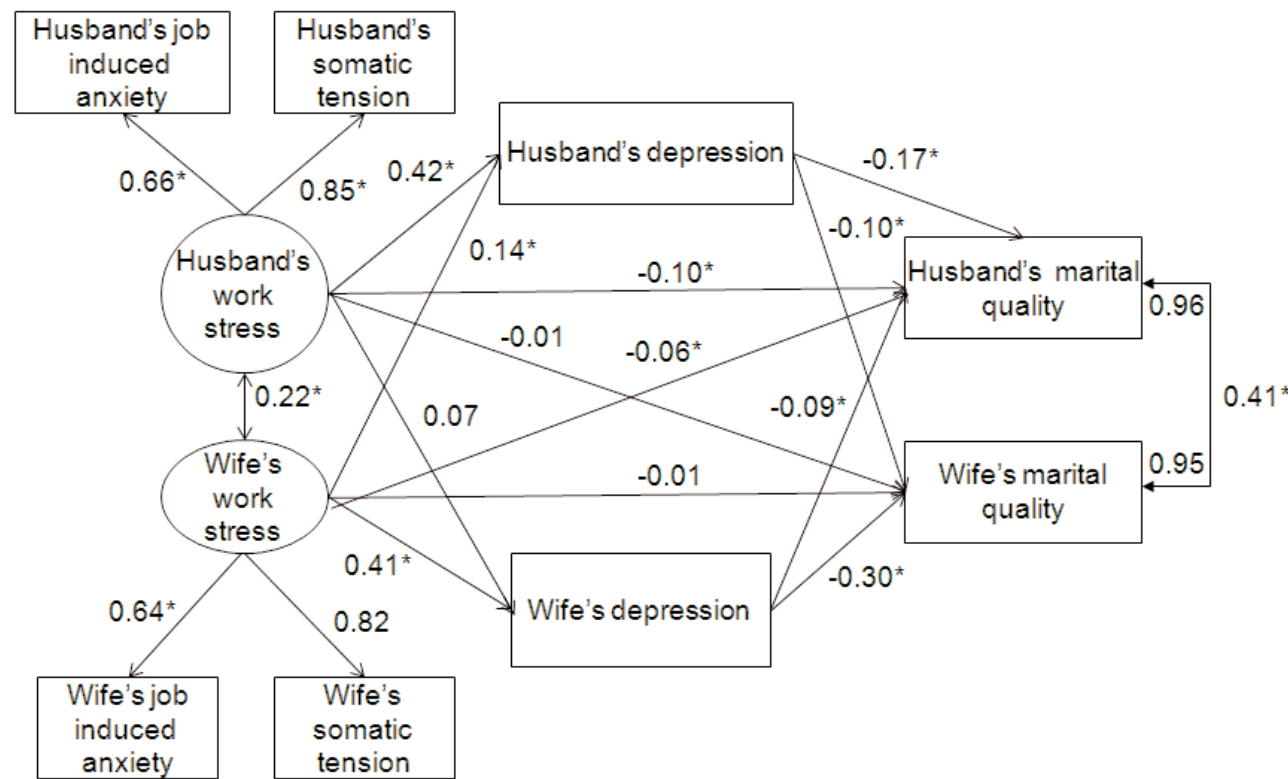

\section{Model comparison}

We used the AIC estimate for a comparison of the models. In terms of the AIC value, the models really differed. The AIC value for Model 1 is 15.814, for Model 2 it is 14.20 and for Model 3 it is 30.081. Consequently, Model 2 best fitted the data. Besides AIC, we calculated the total, indirect and direct effect of all three models, separately for husband's and wife's actor and partner effects as suggested by Ledermann, Macho, and Kenny (2011). The results are presented in Table 3.

The highest husband's total actor effect is in Model 3, $(-0.28)$, while in Model 2 the husband's total partner effect is (-0.09). In comparison, the wife's total actor effect is highest in Model $2(-0.13)$ and the highest partner total effect is also in Model 2 $(-0.13)$. Concerning actor and partner effects for both marital partners, the models differed substantially in terms of direct and indirect effect. Total marital partners' actor indirect effects are highest in Model 3, husband's (-0.08) and wives' (-0.12). Finally, the total husband's actor direct effect is in Model $1(-0.23)$ 
(1) TABLE 3

Total effects, total indirect effects and direct effects in the APIMeM for partners in marital dyad and total wife's actor direct effect is also in Model $1(-0.08)$. Generally, for both marital partners, actor effects are higher than partner effects. All together, if we take those estimates into consideration, $\mathrm{R}^{2}$ and AIC, Model 2 fitted the data best and has the highest explanatory power.

\begin{tabular}{|c|c|c|c|c|}
\hline Effect & Coefficient & Model 1 & Model 2 & Model 3 \\
\hline \multicolumn{5}{|l|}{ Husband actor effect } \\
\hline Total effect & $\mathrm{a}_{\mathrm{A} 1} \mathrm{~b}_{\mathrm{A} 1}+\mathrm{a}_{\mathrm{p} 2} \mathrm{~b}_{\mathrm{p} 1}+\mathrm{c}_{\mathrm{A} 1}^{\prime}$ & -0.26 & -0.18 & -0.18 \\
\hline Total indirect effect & $a_{\mathrm{A} 1} b_{\mathrm{A} 1}+a_{\mathrm{p} 2} \mathrm{~b}_{\mathrm{p} 1}$ & -0.03 & -0.06 & -0.08 \\
\hline Total direct effect & $\mathrm{C}_{\mathrm{A} 1}^{\prime}$ & -0.23 & -0.12 & -0.10 \\
\hline \multicolumn{5}{|l|}{ Wife actor effect } \\
\hline Total effect & $\mathrm{a}_{\mathrm{A} 2} \mathrm{~b}_{\mathrm{A} 2}+\mathrm{a}_{\mathrm{p} 1} \mathrm{~b}_{\mathrm{p} 2}+\mathrm{c}_{\mathrm{A} 2}^{\prime}$ & -0.12 & -0.15 & -0.13 \\
\hline Total indirect effect & $a_{\mathrm{A} 2} b_{\mathrm{A} 2}+a_{\mathrm{p} 1} b_{\mathrm{p} 2}$ & -0.04 & -0.09 & -0.12 \\
\hline Total direct effect & $\mathrm{C}^{\prime} \mathrm{A} 2$ & -0.08 & -0.06 & -0.01 \\
\hline \multicolumn{5}{|l|}{ Husband partner effect } \\
\hline Total effect & $a_{\mathrm{A} 2} b_{\mathrm{p} 1}+\mathrm{a}_{\mathrm{p} 1} \mathrm{~b}_{\mathrm{A} 1}+\mathrm{c}_{\mathrm{p} 1}^{\prime}$ & -0.06 & -0.10 & -0.12 \\
\hline Total indirect effect & $a_{A 2} b_{p 1}+a_{p 1} b_{A 1}$ & -0.05 & -0.06 & -0.06 \\
\hline Total direct effect & $\mathrm{C}^{\prime} \mathrm{p} 1 \mathrm{pi}$ prit & -0.01 & -0.04 & -0.06 \\
\hline \multicolumn{5}{|l|}{ Wife partner effect } \\
\hline Total effect & $a_{\mathrm{A} 1} b_{\mathrm{p} 2}+\mathrm{a}_{\mathrm{p} 2} \mathrm{~b}_{\mathrm{A} 2}+\mathrm{c}_{\mathrm{p} 2}^{\prime}$ & -0.07 & -0.12 & -0.06 \\
\hline Total indirect effect & $a_{\mathrm{A} 1} b_{\mathrm{p} 2}+\mathrm{a}_{\mathrm{p} 2} \mathrm{~b}_{\mathrm{A} 2}$ & -0.02 & -0.06 & -0.05 \\
\hline Total direct effect & $\mathrm{C}_{\mathrm{p} 2}^{\prime}$ & 0.09 & -0.06 & -0.01 \\
\hline
\end{tabular}

\section{DISCUSSION}

Three mediation models were tested with the aim to verify which one fitted the data best and had the greatest explanatory power for the variable Marital quality. The mediating variables were Negative spillover from work to marriage, Marital strain and Depression. Those variables turned out to be predictive for marital quality in previous studies, but all three variables were not included and compared in terms of explanatory power in previous studies. According to the obtained results in this study, using AIC and $\mathrm{R}^{2}$ estimates, the best model is with marital strain as the mediation variable. Those results are logical. The variable Negative spillover from work negatively affects marital quality, but the explained percentage of variance of the variable Marital quality is very small. In other words, the variable Negative spillover negatively affects only some marital partners' marital quality. Many more marital partners' marital strain affects their marital quality and its intensity is higher than is the intensity of negative spillover from work to the marriage. This is very similar with Depression as a mediating variable. In other words, both marital partners experience the indirect effect of work stress more inten- 
DRUŠ. ISTRAŽ. ZAGREB GOD. 22 (2013), BR. 4, STR. 673-691

OBRADOVIĆ, J., ČUDINA-OBRADOVIĆ, M. WORK STRESS... sively if they experience marital strain than if they indirectly experience work stress via negative spillover or depression on their marital quality.

Our hypothesis is that our mediation variables represent a chain of variables, or variables that appear successively. The first negative spillover from work which creates marital strain appears in dyads. Long standing marital strain creates depression among marital partners but evidently it creates depression only among some marital partners, whereby marital partners' marital quality decreases. Since those three mediation variables negatively affect only some marital partners' marital quality, the major question is which variables make some marital partners resilient. These are probably some marital partners' characteristics, but also some specific features of the Croatian social and cultural context, which we know too little about. Thus, the next step in studying the relationship between work stress, mediating variables and marital quality should be identifying the moderators which make some marital partners resilient to work stress. The results of such a study could be very useful to policy makers, especially in a social and economic situation that is generally very difficult and in a country whose population is largely experiencing different types of stress simultaneously.

\section{REFERENCES}

Baloban, J., \& Črpić, G. (2000). Bitne vrednote za uspješan brak u Hrvatskoj (Essential values for a successful marriage in Croatia). Bogoslovska smotra, 70(2), 313-341.

Bentler, P. M. (2006). EQS6 Structural Equations Program Manual. Enciano: Multivariate Software, Inc.

Bentler, P. M., \& Wu, E. (2006). EQS for Windows (version 6.1). Enciano: Multivariate Software.

Bolger, N., DeLongis, A., Kessler, R., \& Wethington, E. (1989). The contagion of stress across multiple roles. Journal of Marriage and Fami$l y, 51(1), 175-183$. doi: $10.2307 / 352378$

Bollen, K. A., \& Long, J. S. (1993). Structural equations with latent variables. New York: Wiley.

Browne, M. W., \& Cudeck, R. (1993). Alternative ways of assessing model fit. In K. A. Bollen, \& J. S. Long (Eds.), Testing structural equation models (pp. 136-162). Newbury Park: Sage.

Cohen, J. (1988). Statistical power analysis for the behavioral sciences (2nd ed.). Hillsdale, NJ: Erlbaum.

Conger, R. D., Rueter, M. A., \& Elder Jr., G. H. (1999). Couple resilience to economic pressure. Journal of Personality and Social Psycho$\log y, 76(1), 54-71$. doi:10.1037/0022-3514.76.1.54

Crouter, A. C., \& Helms-Erikson, H. (1997). Work and family from a dyadic perspective: Variations in inequality. In S. Duck (Ed). Handbook of personal relationships: Theory, research and interventions (2nd ed., 487-503). Chichester, UK: Wiley. 
DRUŠ. ISTRAŽ. ZAGREB GOD. 22 (2013), BR. 4 STR. 673-691

OBRADOVIĆ, J., ČUDINA-OBRADOVIĆ, M. WORK STRESS...
Dipboye, R. L., Smith, C. S., \& Howell, W. (1994). Understanding industrial and organizational psychology: An integrated approach. Fort Worth: Harcourt Brace College Publishers.

Elliott, G. R., \& Eisdorfer, C. (Eds.) (1982). Stress and human health: Analysis, and implications of research. New York: Springer-Verlag.

Ford, M. T., Heinen, B. A., \& Longkamer, K. L. (2007). Work and family satisfaction and conflict: A meta-analysis of cross-domain relations. Journal of Applied Psychology, 92(1), 57-80. doi:10.1037/0021-9010.92.1.57 French, J. R. P., Jr., Caplan, R. D., \& Harrison, R. V. (1982). The mechanism of job stress and strain. Chichester, England: Wiley.

Funk, J. L., \& Rogge, R. D. (2007). Testing the ruler with items response theory: Increasing precision of measurement for relationship satisfaction with Couples Satisfaction Index. Journal of Family Psychology, 21(4), 572-583. doi:10.1037/0893-3200.21.4.572

Goodman, W. B., Crouter, A. C., Lanza, S. T., Cox, M. J., \& Vernon-Feagans, L. (2011). Parental work-stress and latent profiles of father-infant parenting quality. Journal of Marriage and Family, 73(3), 588-604. doi:10.1111/j.1741-3737.2011.00826.x

House, R. J., \& Rizzo, J. R. (1972). Role conflict and ambiguity as critical variables in a model of organizational behavior. Organizational Behavior and Human Performance, 7(3), 467-505. doi:10.1016/0030-5073 (72) $90030-X$

Heyman, R. E., Sayers, S. L., \& Bellack, A. S. (1994). Global marital satisfaction versus marital adjustment: An empirical comparison of three measures. Journal of Family Psychology, 8(4), 432-446. doi:10. 1037/0893-3200.8.4.432

Hu, L., \& Bentler, P. M. (1998). Fit indices in covariance structure modeling: Sensitivity to underparematrized model misspecification. Psychological Methods, 3(4), 424-453. doi:10.1037/1082-989X.3.4.424

Jacobs, P. A., Tytherleigh, M. Y., Webb, C., \& Cooper, C. L. (2007). Predictors of work performance among higher education employees: An examination using the ASSET Model of Stress. International Journal of Stress Management, 14(2), 199-210. doi:10.1037/1072-5245.14.2.199

Jones, F., Burke, R., Ronald, J., \& Westman, M. (Eds) (2006). Work-life balance: A psychological perspective. New York: Psychology Press.

Kahn, R. L., \& Byosiere, P. (1992). Stress in organizations. In M. D. Dunnete, \& L. M. Hough (Eds), Handbook of industrial and organizational psychology (Vol. 3, 2nd ed., pp. 571-650). Palo Alto, CA: Consulting Psychologist Press.

Kenny, D. A. (1996). Model of non-independence in dyadic research. Journal of Social and Personal Relationships, 13(2), 279-294. doi:10.1177/ 0265407596132007

Kenny, D. A, Kashy, D. A., \& Cook, W. L. (2006). Dyadic data analysis. New York: Guilford Press.

Lavee, Y., \& Ben-Ari, A. (2007). Relationship of dyadic closeness with work-related stress: A daily diary study. Journal of Marriage and Family, 69(4), 1021-1035. doi:10.1111/j.1741-3737.2007.00428.x

Ledermann, T., \& Macho, S. (2009). Mediation in dyadic data at the level of the dyads: A structural equation modeling approach. Journal of Family Psychology, 23(5), 661-670. doi:10.1037/a0016197 
DRUŠ. ISTRAŽ. ZAGREB GOD. 22 (2013), BR. 4, STR. 673-691

OBRADOVIĆ, J., ČUDINA-OBRAD'OVIĆ, $M$. WORK STRESS...
Ledermann, T., Macho, S., \& Kenny, D. A. (2011). Assessing mediation in dyadic data using the actor-partner interdependence model. Structural Equation Modeling: A Multidisciplinary Journal, 18(4), 595-612. doi:10.1080/10705511.2011.607099

Lewin-Epstein, N. (1989). Work characteristics and ill health. Gender differences in Israel. Work and Occupations, 16(1), 80-104. doi:10.1177/ 0730888489016001005

MacCallum, R. C., Browne, M. W., \& Sugawara, H. M. (1996). Power analysis and determination of sample size for covariance structure modeling. Psychological Methods, 1(2), 130-149. doi:10.1037/1082-989 X.1.2.130

MacEwen, K. E., Barling, J., \& Kelloway, E. K. (1992). Effects of short-term role overload on marital interactions. Work and Stress, 6(2), 117-126. doi:10.1080/02678379208260346

McCubbin, H. I., Thompson, A. I., \& McCubbin, M. A. (1996). Family inventory of life events and changes. In H. I. McCubbin, A. I. Thompson, \& M. A. McCubbin (Eds.), Family assessment: Resiliency, coping and adaptation - inventories for research and practice (pp. 78-80). Madison, Wisconsin: University of Wisconsin Publishers.

Norton, R. (1983). Measuring marital quality: A critical look at the dependent variable. Journal of Marriage and Family, 45(1), 141-151. doi: $10.2307 / 351302$

Paden, S. L., \& Buehler, C. (1995). Coping with the dual-income lifestyle. Journal of Marriage and Family, 57(1), 101-110. doi:10.2307/353819

Perry-Jenkins, M., Repetti, R. L., \& Crouter, A. C. (2000). Work and family in the 1990s. Journal of Marriage and Family, 62(4), 981-998. doi:10. 1111/j.1741-3737.2000.00981.x

Radloff, L. S. (1977). The CES-D Scale: A Self-Report Depression Scale for research in the general population. Applied Psychological Measurement, 1(3), 385-401. doi:10.1177/014662167700100306

Repetti, R. L., \& Saxbe, D. (2009). The effects of the job stress on the family: One size does not fit all. In D. R. Crane, \& J. E. Hill (Eds.), Handbook of families $\mathcal{E}$ work (pp. 62-78). New York: University Press of America.

Roberts, N. A., \& Levenson, R. W. (2001). The remains of the workday: Impact of job stress and exhaustion on marital interaction in police couples. Journal of Marriage and Family, 63(4), 1052-1067. doi:10. 1111/j.1741-3737.2001.01052.x

Rook, K., Dooley, D., \& Catalano, R. (1991). Stress transmission: The effects of husbands' job stressors on the emotional health of their wives. Journal of Marriage and Family, 53(1), 165-177. doi:10.2307/353141

Schneewind, K., \& Kupsch, M. (2007). Patterns of neuroticism, work-family stress, and resources as determinants of personal distress. A cluster analysis of young, dual-earner families at the individual and couple level. Journal of Individual Differences, 28(3), 150-160. doi:10.1027/1614-0001.28.3.150

Sears, H. A., \& Galambos, N. L. (1992). Women's work conditions and marital adjustment in two earner couples: A structural model. Journal of Marriage and Family, 54(4), 789-797. doi:10.2307/353161 
DRUŠ. ISTRAŽ. ZAGREB GOD. 22 (2013), BR. 4 STR. 673-691

OBRADOVIĆ, J., ČUDINA-OBRADOVIĆ, $M$ : WORK STRESS...
Selye, H. (1950). The physiology and pathology of exposure to stress. Montreal, Quebec, Canada: Acta.

Small, S. A., \& Riley, D. (1990). Toward a multidimensional assessment of work spillover into family life. Journal of Marriage and the Family, 52(1), 51-61. doi:10.2307/352837

Steenbergen, E. F., Kluwer, E., \& Karney, B. (2011). Workload and the trajectory of marital satisfaction in newlyweds: Job satisfaction, gender and parental status as moderators. Journal of Family Psychology, 25(3), 345-355. doi:10.1037/a0023653

Story, L. B., \& Repetti, R. (2006). Daily occupational stressors and marital behavior. Journal of Family Psychology, 20(4), 690-700. doi:10.1037/ 0893-3200.20.4.690

Westman, M. (2001). Stress and strain crossover. Human Relations, 54(6), 717-751. doi:10.1177/0018726701546002

Westman, M., Vinokur, A. D., Hamilton, L. V., \& Roziner, I. (2004). Crossover of marital dissatisfaction during military downsizing among Russian army officers and their spouses. Journal of Applied Psychology, 89(5), 769-779. doi:10.1037/0021-9010.89.5.769

\section{Radni stres i kvaliteta braka zaposlenih bračnih partnera: provjera triju posredničkih modela Josip OBRADOVIĆ, Mira ČUDINA-OBRADOVIĆ Zagreb}

Provedeno je istraživanje na 340 zaposlenih bračnih parova koji predstavljaju proporcionalni kvotni uzorak zaposlenih za Grad Zagreb i Zagrebačku županiju. Cili je istraživanja bio provjeriti posredno djelovanje doživljaja radnoga stresa na kvalitetu braka bračnih partnera. Konstruirana su tri teoretska modela. U prvom je modelu posrednička varijabla bila percepcija negativnoga prijenosa iz rada, u drugom doživliaj bračnoga stresa, a u trećem depresija. Za provjeru posrednoga dielovanja radnoga stresa na kvalitetu braka primijenjeno je modeliranje strukturalnim jednadžbama, i to ML ROBUST. Rezultati istraživanja pokazuju da radni stres posredno djeluje na kvalitetu braka. Za sva tri modela dobiveni su rezultati koji pokazuju da postoji slaganje između svakoga modela i podataka, ali se snaga modela bitno razlikuje. Najsnažniji se pokazao model u kojem je posrednička varijabla bila bračni stres. Tim je modelom objašnjeno $26 \%$ varijance varijable kvalitete braka žena i $17 \%$ varijance kvalitete braka muževa. U radu se raspravljaju dobiveni rezultati i upućuje kamo i u kojem smjeru trebaju ubuduće ići istraživanja ovoga problema.

Ključne riječi: radni stres, negativni prijenos, bračni stres, depresija, kvaliteta braka 